\title{
Coal Technology Program Progress Report for December 1975
}

\section{MASTER}

\section{OAK RIDGE NATIONAL LABORATORY}

OPERATED BY UNION CARBIDE CORPORATION - FOR THE U.S. ATOMIC ENERGY COMMISSION 


\section{DISCLAIMER}

This report was prepared as an account of work sponsored by an agency of the United States Government. Neither the United States Government nor any agency Thereof, nor any of their employees, makes any warranty, express or implied, or assumes any legal liability or responsibility for the accuracy, completeness, or usefulness of any information, apparatus, product, or process disclosed, or represents that its use would not infringe privately owned rights. Reference herein to any specific commercial product, process, or service by trade name, trademark, manufacturer, or otherwise does not necessarily constitute or imply its endorsement, recommendation, or favoring by the United States Government or any agency thereof. The views and opinions of authors expressed herein do not necessarily state or reflect those of the United States Government or any agency thereof. 


\section{DISCLAIMER}

Portions of this document may be illegible in electronic image products. Images are produced from the best available original document. 
Printed in the United States of America. Available from National Technical Information Service

U.S. Department of Commerce

5285 Port Royal Road, Springfield, Virginia 22161

Price: Printed Copy \$5.00; Microfiche $\$ 2.25$

This report was prepared as an account of work sponsored by the United States Government. Neither the United States nor the Energy Research and Development Administration, nor any of their employees, nor any of their contractors, subcontractors, or their employees, makes any warranty, express or impiied, or assumes any legal liability or responsibility for the accuracy, completeness or usefulness of any information, apparatus, product or process disclosed, or represents that its use would not infringe privately owned rights. 
Contract No. W-7405-eng-26

COAL TECHINOLOGY PROGRAM

PROGRESS REPORT FOR DECEMBER 1975

\section{FEBRUARY 1976}

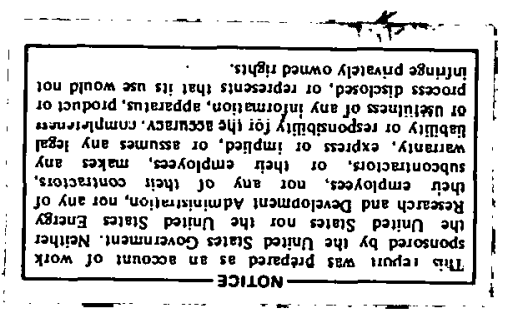

NOTICE This document contains information of a preliminarv nature and was prepared primarily for internal use at the Oak Ridge National Laboratory. It is subject to revision or correction and therefore does not represent a final report.

\footnotetext{
OAK RIDGE NATIONAL LABORATORY

Oak Ridge, Tennessee 37830

operated by

UNION CARBIDE CORPORATION

for the

ENERGY RESEARCH AND DEVELOPMENT ADMTNISTRATION
} 
PREVIOUS REPORTS IN THIS SERIES

ORNL-TM-5044, Progress Report for August 1974

ORNL-TM-5045, Progress Report for September 1974

ORNL-TM-5046, Progress Report for October 1974

UKNL-'IM-4787, Frogress Report for Nuvember 1974

ORNL-TM-4796, Progress Report for December 1974

ORNL-TM-4850, Progress Report t'or January 1975

ORNL-TM-4873, Progress Report for February 1975

ORNL-TM-4892, Progress Report for March 1975

ORNL-TM-4946, Progress Report for Apri $19^{\prime} / 3$

ORNL-TM-4966, Progress Report for May 1975

ORNL-TM-5010, Progress Report for June 1975

ORNL-TM-5037, Progress Report for July 1975

ORNL-TM-5092, Progress Report for August 1975

ORNL-TM-5124, Progress Report for September 1975

ORNL-TM-5186, Progress Report for October 1975

ORNL-TM-5214, Progress Report for November 1975 


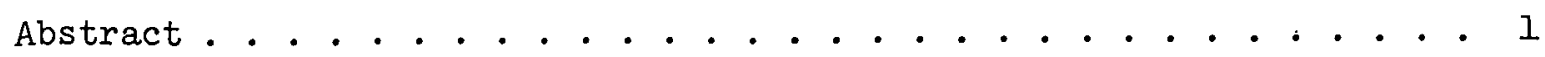

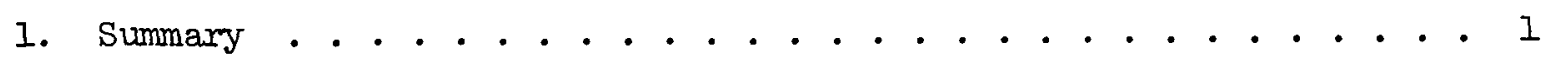

2. Hydrocarbonization Research ............. 3

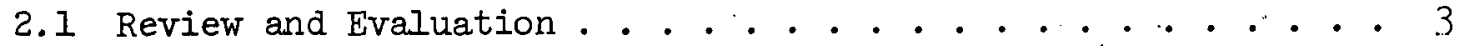

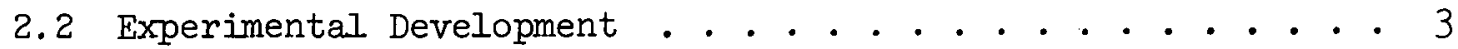

2.3 Bench-Scale System .............. . . . . . . . . . . . . . . . .

2.4 Residua Carbonization .............. 5

3. Supporting Research and Development on

Separations Technology ................ 7

4. Chemical Research and Development ............ . 9

4.1 Physical structure of coal ............. 9

5. Engineering Evaluations of Nuclear Process Heat

for Coal Conversion ................... 10

6. Engineering Evaluations of the Synthoil and Hydrocarbonization Processes . . . . . . . . . . . . Il

6.1 Synthoil Process ............... 12

6.2 Hydrocarbonization Process ............ 14

7. Coal-Fueled MIUS . . . . . . . . . . . . . 15 
COAL TECHINOLOGY PROGRAM PROGRESS REPORT FOR DECEMBER 1975

\begin{abstract}
This report - the seventeenth of a series - is a compendium of monthly progress reports for the ORNL research and development projects that are in support of the increased utilization of coal as a source of clean energy. The projects reported this month include those for hydrocarbonization, solid-liquid separations, chemical research and development, engineering evaluations of nuclear process heat for coal conversion, engineering evaluations of the Hydrocarbonization and Synthoil processes, and coal-fueled MIUS.
\end{abstract}

1. SUMMARY

J. P. Nichols

Highlights of our progress in December are summarized below:

- Two more runs have been completed with the bench-scale system in hydrocarbonization research using nitrogen at 20 atm with the preheater at $1400^{\circ} \mathrm{F}$ and the reactor at $1250^{\circ} \mathrm{F}$. Some difficulty was encountered with the coal feeder and corrective modifications are underway. After one more run with nitrogen, hydrogen will be introduced into the system.

- In supporting research and development on separations technology, batch settling studies have shown that good results are obtained at $150^{\circ} \mathrm{C}$ and $20 \%$ toluene concentrations. Continuous settling studies were initiated to evaluate the effects of some parameters of a continuous flow system. Construction of the l-liter bench-scale apparatus was completed for conductivity settling characteristic studies.

- Activities in chemical research and development continue with the development of a small-angle $x$-ray scattering (SAXS) method to study the porosity of coal.

- In engineering evaluations of nuclear process heat from coal conversion revisions and additions have been made to a flowsheet for a plant producing synthesis gas using the direct steam gasification of coal which is thermally driven by a 3000-MW(t) VHTR. 
- In the engineering evaluations work for Synthoil, process flow diagrams for four units were finalized. A preliminary facility site plan has been developed. Conceptual design of the solids-liquid separation plant specifying centrifugation followed by filtration of the thickened underflow was completed. For Hydrocarbonization, material balances for various units are under preparation. Based on interim results, a hydrocarbonization system will be recommended for evaluation as a demonstration plant.

- In the MIUS program, a $1 / 12$ scale model of the latest layout is being constructed. Tests with the 4-ft-square cold flow unit have been resumed. A larger motor has been installed on the Iron Fireman to provide the power required for operation with cold air. 


\section{HYDROCARBONIZATION RESEARCH}

H. D. Cochran, Jr.

Summary

During December two runs were made with the bench-scale system using nitrogen as the feed gas at full system temperature and pressure. Both runs were hampered by difficulties with the coal feeder, but otherwise the system operated well. The coal feeder assembly has been modified and appears to operate satisfactorily at atmospheric pressure. During January one more run will be made with nitrogen to demonstrate satisfactory operation of the whole system including the feeder. Full data acquisition and cample analyses will be performed to permit calculation of' a material balance. First operation with hydrogen is scheduled to follow this run immediately.

\subsection{Review and Evaluation}

(Completed)

\subsection{Experimental Development}

J. B. Gibson, P. R. Westmoreland, and J. C. Rose

Work Accomplished

Ambient Mock-Ups. Effort on this part of the project has been curtailed.

High-Temperature Studies. Run AHC-9 was completed successfully in early December, and samples were submitted for chemical analysis. Reaction conditions were identical to AHC-8, except that maximum temperature was $1000^{\circ} \mathrm{F}\left(540^{\circ} \mathrm{C}\right)$ instead of $1060^{\circ} \mathrm{F}\left(570^{\circ} \mathrm{C}\right)$.

After sampling and clean-up following AHC-9, installation of a recirculating fluidized-bed reactor and its associated subsystems was begun. This modification continued at the end of the reporting period and is described separately in the report on the Residua Carbonization project.

Preliminary chemical analyses indicate near-complete recovery of carbon in the reaction products. Approximately $12 \%$ of the carbon was recovered in the condenser system. 


\section{Work Forecast}

Ambient Mock-Ups. No effort is planned in this area during the next month.

High-Temperature Studies. Shakedown and initial results from the recirculating fluidized bed reactor will be accomplished by AHC-10, a duplication of AHC-8 in other aspects. Atmospheric hydrocarbonization experiments will continue, pending final preparations for residua carbonization.

\subsection{Bench-ícale System}

H. D. Cochran, Jr, , G. L. Yoder, and K. L. Andrews

Work Accomplished

Fabrication and Installation. Several ancillary components of the bench-scale systems were completed during the month. The cold trap, which had not been operated previously, was completed with the installation of cooling coils and the coolant circulation system. Temperatures between ambient and about $-70^{\circ} \mathrm{C}$ can be obtained by varying the circulation rate of dry ice temperature $\left(-78.5^{\circ} \mathrm{C}\right)$ coolant through the coils.

Hook-up of remaining thermocouples and pressure switches was completed. Over-temperature and over-pressure alarms, displayed on the panel board, are now operational. Work is nearly completed on the balance of the alarm/emergency shut-down circuitry. Other work on instruments and controls included start-up and successful shakedown testing of the on-line process gas chromatograph, completion of balanc1ng pressure control on the scrubbcr pump (manual control, whlch has been used to date, 13 not pructical with hydrogen pressure in the system), and completion and testing of the fire detection sensors in the equipment room.

As a result of difficulties with the coal feeder during the two runs with nitrogen at $20 \mathrm{~atm}$ (reported below), the coal feeder was milified as follows: (1) the feed hopper is aerated and pressurized with the gas used for pneumatic transport of feed coul, ("2) the packing in the ball valve coal feeder was replaced, and (3) the pneumatic transport gas is directed to impinge on the downstream side of the feeder valve to break up loose compacts in the feeder. Testing of the modlfled feeder at atwospheric pressure was completed successfully, and tests at 20 atm are underway.

Construction of the hydrogen trailer station is very nearly completed; about 1 week of work remains. Two hydrogen tube trailers, owned by Union Carbide Nuclear Division, have been assigned to this project. The supply station and trailers will be available in time for the first run with hydrogen scheduled for next month. 
Operation. During December two runs were made using nitrogen as feed gas at fuzl system design pressure, $20 \mathrm{~atm}$, and temperature, preheater walls, $1400^{\circ} \mathrm{F}$, and reactor walls, $1250^{\circ} \mathrm{F}$. Both muns were hampered by difficulties in maintaining coal feed. Otherwise all parts of the benchscale system operated without problems.

Coal feeding problems appeared to result from bridging in the feed hopper and/or formation of loose compacts of coal in the cavities of the feeder valve. Both phenomenon were observed during examination and testing of the feeder after the second run. Neither problem had been observed during atmospheric pressure tests or during runs at 5 atm pressure. Several modifications to the feeding system (described above) have been made in an attempt to solve this problem.

It is likely that the feeder problems have been aggravated by the large amount of fines in the feed coal. Earlier tests and runs had been performed with small batches of coal prepared with a small mill and an 8-in.-diam sieve shaker. The hammer mill and 18-in.-diam sieve shaker which were used to prepare the larger batches of coal for the two 20-atm runs produce a feed with a large amount of fines ( 20 wt $\%<10 \mu$ ) which are difficult to remove from the feed. Further tests are planned with the 18-in. sieve shaker to reduce the amount of fines in the feed coal.

Work Forecast

Design and Review. Design work will be initiated for modification of the system to permit operation at pressures up to 80 atm of hydrogen.

Fabrication and Installation. Remaining details of the bench-scale system will be completed during the next month.

Operation. One further run with nitrogen at $20 \mathrm{~atm}$ pressure is planned to demonstrate satisfactory operation of the full system including the coal feeder. Complete data acquisition and sample analysis will be performed to permit calculations of a material balance. First operation of the system with hydrogen is scheduled to follow this nitrogen run immediately.

\subsection{Residua Carbonization}

H. D. Cochran, Jr., and J. B. Gibson

\section{Summary}

This project for supporting research and development on residua carbonization is supported by the Division of Coal Conversion and Utilization of ERDA. The work in the year beginning November 1, 1975, consists of three tasks: (1) a review and evaluation of experience with the lowtemperature carbonizer in the Cresap, West Virginia, pilot plant, (2) modification of an existing reactor to permit continuous feed of 
solids-laden residua, and (3) operation of the reactor with three feedstocks (vacuum distillation bottoms from the $\mathrm{H}$-Coal process and solvent extraction underflows from SRC and CSF product liquids) at three temperatures up to $1200^{\circ} \mathrm{F}$.

\section{Work Accomplished}

Modifications to the bench-scale reactor and installation of the modified reactor have been completed. A second preheater, fabricated of 100 ft of coiled tubing in a clam shell heater, will be used to heat the gas stream which fluidizes the downcomers of the reactor. Design of a feed system and a char overflow pot are essentially complete and fabrication will start shortly. Finely ground particles of residua will be fed via pneumatic transport from the feed vessel to the reactor.

A second feed system is being investigated should the first not prove to be successful. This second feed system consists of mixing the residua with toluene to form a slurry which is 25 to $50 \%$ toluene by weight. The slurry would then be pumped and sprayed into the reactor. The char overflow pot will allow continuous operation of the reactor with respect to char. Continuous operation is necessary for runs that last more than 1 to $2 \mathrm{hr}$. The char level will be determined by connecting the char overflow pot to one of two overflow legs and plugging the other leg.

\section{Work Forecast}

The first draft of the review and evaluation of the Cresap carbonizer should be completed within the month. Fabrication and installation of the feed vessel and char overflow pot should be accomplished. 


\section{SUPPORTING RESEARCF AND DEVELOPMENT ON SEPARATIONS TECHNOLOGY}

B. R. Rodgers

Detailed results for this month are included in the ORNL-Coal Technology quarterly report covering October, November, and December (ORNL-5120). Consequently, this month's results are reported only in summary form.

\section{$\underline{\text { Surmary }}$}

S. Katz, P. R. Westmoreland, B. R. Rodgers, and D. A. McWhirter

Reported accomplishments during this period have occurred in five areas: batch settling studies, continuous settling studies, additive agglomeration studies, bench-scale development, and characterization studies. Solvent Refined Coal (SRC) unfiltered and filtered oils (UFO and FO) have been used exclusively as test materials. Some comparisons are made between SRC oils derived from Illinois \#6 coal (material used in previous tests) and Pittsburgh \#8 coal (material used in current tests). Future tests will use oils derived from the Pittsburgh seam coal.

Batch settling studies covering solvent-to-oil ratios from zero to 0.25 and a temperature range from 150 to $250^{\circ} \mathrm{C}\left(302-482^{\circ} \mathrm{F}\right)$ failed to find the optimum combination of these variables. The best results were obtained at $150^{\circ} \mathrm{C}$ and $20 \%$ toluene concentration, a corner of the experimental matrix. It is planned to continue these lab-scale tests in the bench-scale apparatus.

Continuous settling studies were initiated to evaluate the effects of some parameters of a continuous flow system. Only a small amount of data has been obtained thus far, and these studies will have low priority in the experimental plan. When these studies are completed, the lab-scale data will be used to make an economic evaluation of a continuous settling operation.

Additive agglomeration studies using solid additives has been an ongoing low priority effort since April 1975. Tests of fifteen separate materials have failed to yield positive results to date, and this effort has been abandoned. However, excellent results were obtained this quarter using liquid additives designed for the petroleum industry. Twenty-four proprietary additives were tested; one gave excellent clarification of upper fractions from a settling test; and three others gave good clarification. The results appear to be valid over a range of temperatures. 
Construction of the l-liter bench-scale apparatus was completed. Pneumatic pressure tests revealed a few inadequacies, and these were corrected. The integrity of the apparatus was tested at 330 psig air pressure (110\% design pressure) for one hour. Preliminary operation tests using filtered oil verified the operability of other system components such as heaters. controllers, recorders, etc. The initial run with SRC-UFO indicated that settling characteristics were similar to those obtained with the lab-scale apparatus.

Characterization studies of SRC oils include aging tests, electron microscope particle size distributions, gel permeation chromatography, viscosity-temperature measurements, and vapor pressure measurements. Spectrographic analyses were made of Illinois \#6 and Pittsburgh \#8 coals. Details of these results are included in the quarterly report. 


\title{
4. CHEMICAL RESEARCH AND DEVELOPNEIVT
}

\author{
G. P. Smith
}

The primary activity for the month was to bring on-line a new tool for the study of the porosity of coal, namely, small-angle $x-r a y$ scattering (SAXS). This method of study. is sensitive to fluctuations in electron density on a size-scale of $10-10,000 \AA$ and is expected to give information on the size and size distribution of scattering centers (e.g., voids), their number density, and their total surface area. The method, of course, has some deficiencies but these can probably be overcome with the aid of data supplied by our parallel program on transmission electron microscopy.

This research is supported by ERDA's Division of Physical Research.

\subsection{Physical Structure of Coal}

R. W. Hendricks, L. A. Harris and C. S. Yust

Small-angle $x$-ray scattering experiments were carried out on two specimens of a high-volatile bituminous coal. Both samples were originally examined by optical microscopy and high-angle x-ray diffraction and found to be low in mineral matter, which would otherwise complicate interpretation of the small-angle data. A strong scattering pattern was observed and these data are now under study. 
5. ENGTNEERING EVALUATTONS OF NUCLEAR PROCESS

HEAT FOR COAL CONVERSION

W. R. Gambill

The Institute of Gas Technology final report on hydrogen was received and partially reviewed. The report (three volumes) is titled "Survey of Hydrogen Production and Utilization Methods" and addresses the following topics: potential demands; production by electrolysis, from coal, via thermochemical cycles, and by photosynthetic and other processes; current commercial generation technology (reforming and partial oxidation); transmission, storage, and distribution; industrial and residential utilization; and R\&D recommendation:

Revisions and addltzons were made to a rluwsluet fur te plant producing synthesis gas by the direct steam gasification of coal and thermally driven by a 3000-MW( $t$ ) VHTR. The final molar ratio of $\mathrm{H}_{2}$ to $\mathrm{CO}$ is 2.95 to 1 , and the overall plant efficiency is $\sim 75 \%$.

The writer attended a course in New Jersey from December 8 to 10 arranged by the Center for Professional Advancement on the topic of Chemical Reactor Engineering.

We met with representatives of United Engineers and Constructors (Philadelphia) on December 23 to review their semifinal results on two subcontract studies, titled "Evaluation of a Coal Liquefaction Process Using Either a Nuclear or Fossil Heat Source" and "An Evaluation of Pollution and Water Consumption Related to Selected Coal Conversion Processes," each of which will be reported in final form in January 1.976. The former study is of the H-Coal process using either a combusti.nn- or a convectively-heated reformer section and shows somewhat higher. production costs for the He-heated reformer, though the heating value of the net crude-liquid and gas production is $17.6 \%$ higher than for the all-coal plant for the same coal feed rate of 60,000 TPD. In each case, the overall energy conversion efficiency is approximately 65\%. Briefly, the latter study shows that plants utilizing nuclear process heat are characterized by projected $\mathrm{SO}_{\mathrm{x}}$ and $\mathrm{NO}_{\mathrm{x}}$ emissions 5 to 30 fold smaller than the fossil plants, but that the poliutant outputs ot the nonnuclear plants would be well below EPA power plant standards. 
6. ENGINEERING EVALUATIONS OF THE SYNTHOIL AND HYDROCARBONIZATION PROCESSES

J. M. Holmes, R. Salmon, and E. G. St. Clair

Summary

Synthoil. Process flow diagrams for four units were finalized, along with heat and material balances, and equipment lists, the two CO shift units, and two acid gas removal units. The computer code used to calculate heat and material balances for CO shift plants was augmented to include cobalt molybdate catalyst. Various heat exchange equipment specifications were forwarded to Nooter Corporation for rating and pricing. A preliminary Synthoil facility site plan was developed. Conceptual design of the solids-liquid separation plant specifying centrifugation followed by filtration of the thickened underflow was completed. Equipment sizing and costing is underway. Equipment sizing was also in progress in the Gasification and Low-Temperature Carbonization plants, assisted by computer models. Equipment listing and costing were undertaken in the coal handling and preparation plant. A change in coal breaker size was made; because the $2000-t o n / h r$ machine is only in the planning stage, the presently available 1000-ton/hr breaker will be specified.

Hydrocarbonization. Material balances for various units are under preparation now that a firm overall material balance has been chosen. Based on interim results, a hydrocarbonization system will be recommended for evaluation as a demonstration plant. The McNally-Pittsburg Corporation has continued preparation of a design and cost estimate for the coal beneficiation plant. A revised flowsheet was received which includes cyclones to split plus and minus 100 mesh material and driers for coal product streams. Maximum recycle gas temperature leaving the fluid bed combustion unit was reduced to $1450^{\circ} \mathrm{F}$ to prevent the coking encountered by U.S. Steel at higher temperatures. To make'up the additional heat required in the Stage II hydrocarbonizer, a char burner was included. Approval was received for the fluid bed combustor design and cost estimate subcontract with the Fluid Bed Combustion Company. Equipment sizing was initiated on the finalized fuel oil--solids separation plant. The overall plant capital cost was estimated at about $\$ 10$ million. The Benfield Corporation was contacted for the conceptual design and cost of two $\mathrm{CO}_{2}$ removal plants using $\mathrm{K}_{2} \mathrm{CO}_{3}$. Remaining acid gas separation plants will be designed for DEA systems. 


\subsection{Synthoil Process}

R. Salmon, E. G. St. Clair, M. S. Edwards, W. C. Ulrich, and D. A. Dyslin

Heat and material balances and equipment lists were developed for the following units:

$\begin{array}{ll}\text { Unit } 14 & \text { High Temperature CO Shift } \\ \text { Unit 20 } & \text { Low Temperature CO Shift } \\ \text { Unit } 19 & \text { Raw Gas Treating } \\ \text { Unit 21 } & \text { Shifted Gas Final } \mathrm{CO}_{2} \text { Removal }\end{array}$

Computer codes were written to calculate heat and material balances for the hot carbonate and DEA gas treating processes. The former was used to supplement data received from Bentield Corporation.

Computer codes (previously written) to calculate heat and material balances for the $\mathrm{CO}$ shift units were augmented with new data supplied by Girdler Catalysts, Inc., using cobalt molybdate catalyst.

Process flow diagrams for the units listed above were finalized. other areas of the Synthoil flowsheet have progressed as follows:

(1) Equipment Selection and Plant Layouts: The Synthoil filter gas recycle compressors were sized and selected. The data sheets and associated material balances for the high-temperature $\mathrm{CO}$ shift unit reactor effluent cooler, 50 psig steam generator, and shifted gas cooler were forwarded to Nooter Corporation for rating and pricing information. A preliminary Synthoil plant complex site plan was developed.

The Hydrocarbonization filter gas recycle compressor was sized and selected.

(2) Solids-Liquid Separation: The conceptual designs of the solidsliquid separation plants for Hydrocarbontzation and Synthuil were completed. Equipment sizing and costing, and utility requirements are currently being determined.

In the Hydrocarbonization facility, five pressure precoat rotary drum f'ilters will be required, w1th $500 \mathrm{ft}^{2}$ filtering area each. The preliminary capital cost estimate for the entire filtration plant is about $\$ 10$ million, with an operating expense for precoat (in the form of coal at $\$ 20 \%$ ton) of $\$ 120 /$ day. The remaining operating expenses are primarily dependent on the utilities, which are now being determined.

The Synthoil solids-liquid separation plant is much larger than for the Hydrocarbonization process, due to the higher throughput of liquid products. Because the product is more viscous, Synthoil also requires a 
higher operating temperature for filtration or centrifugation ( 450 to $550^{\circ} \mathrm{F}$ vs $350^{\circ} \mathrm{F}$ in the Hydrocarbonization process). Hence, diatomaceous earth is required for precoating filters, since coal cannot be used at temperatures much over $500^{\circ} \mathrm{F}$ because of melting. To reduce the cost of the separation plant, centrifugation was considered. Although it is not clear yet whether centrifugation alone can perform the separation satisfactorily, the use of centrifuges as a thickening step does appear both feasible and economically desirable. The partially clarified overflow from centrifugation would be recycled to the coal slurrying section. The savings in purchased equipment cost alone, considering the use of centrifuges followed by filters vs only filters, is over $\$ 50$ million $\$ 24$ million vs $\$ 77$ million). Diatomaceous earth costs are reduced from about $\$ 11,000 /$ day to about $\$ 2,300 /$ day. Hence, filtration alone will not be considered as an alternative. The alternatives now under evaluation are centrifugation alone or centrifugation followed by filtration.

Sizing and costing of the Synthoil solids-liquid separation plant is underway. Utilities remain to be determined.

(3) Gas Treatment: Design of the acid-gas separation plants required in Synthoil and Hydrocarbonization was initiated. Three of these plants for the Synthoil process were conceptually designed and costed by the Benfield Corporation, using their modified $\mathrm{K}_{2} \mathrm{CO}_{3}$ process. The remaining two are designed for a DEA process.

Work is underway to complete the DEA computer model, for which an additional equipment macro subroutine had to be developed and inserted in the Phillips' Process Design Analysis (PDA) program containing the remaining plant model. The subroutine has been integrated with the PDA system and is present.ly being debugged.

A request for three plant designs in the Hydrocarbonization facility was sent to the Benfield Corporation. The remaining areas requiring acidgas separation will be designed for DEA treating, using the same PDA model described above.

(4) Gasification: A computer program for calculating the gasifier unit flowsheet material and heat balances was completed and used to size equipment needed for the unit. Equipment Lists were tabulated, and a preliminary plot plan of the unit was prepared.

(5) Low-Temperature Carbonization: A computer program for calculating the low-temperature carbonizer unit flowsheet material and heat balances was completed. Work was started on sizing and tabulating the equipment needed for the unit. 
(6) Coal Handling and Preparation: The flowsheet and the layout plan for the Synthoil coal preparation facility was revised. It was discovered that the 2000-ton/hr Bradford breakers are only in the planning stage, so a change was made to use the available 1000-ton/hr machines. Also, the pulverizer-dryer layout was revised based upon information obtained from Combustion Engineering Corporation. Equipment

lists for the Synthoil coal preparation system are being prepared and cost information on this equipment is being obtained from vendors. Combustion Engineering Corporation agreed to provide an equipment layout and cost information for the pulverizers, dryers, and auxiliary equipment.

\subsection{Hydrocarbonization Process}

J. M. Holmes, D. E. Joy, G. R. Feterson, M. S. Edwards, C. B. Smith, and D. A. Dyslin

An overall material balance has been firmed using hydrocarbonization yields estimated from U.S. Steel's "Clean Coke" PDU. Material balances for the various units in the plant are currently under preparation. The design of major equipment items in the plant has also been started.

The scope of work for the engineering evaluations indicates that during the current studies, either a Hydrocarbonization or a Synthoil system would be selected for evaluation as a scaled-down demonstration plant. Based upon interim results, a Hydrocarbonization system will be recommended for this demonstration plant.

The various sections of the Hydrocarbonization flowshet have progrebied as follows:

(1) Coal Beneficiation: Preparation of a design and cost estimate for the coal beneficiation system continued at the McNally-Pittsburg Corporation. A revised flowsheet was received which includes cyclones for separating the plus and minus 100 mesh material and dryers for removing moisture from the high- and low-grade coal product streams. Petrocarb Incorporated agreed to furnish design and cost data for the coal injection system required for feeding the pressurized reactors in the Hydrocarbonization unit.

(2) Hydrocarbonization: A char burner was included in the Hydrocarbonization flowsheet to provide' a portion of the heat required for the Stage II hydrocarbonizer. The char burner will heat char rapidly to $1700^{\circ} \mathrm{F}$ by burning a small fraction of it with air in an external lift leg arrangement. This change to the Hydrocarbonization unit was necessary because of recent coking problems encountered by U.S. Steel while heating recycle gases containing hydrocarbons to $1750^{\circ} \mathrm{F}$. The maximum recycle gas temperatures leaving the fluid bed combustion unit were reduced to $1450^{\circ} \mathrm{F}$ to circumvent this problem.

(3) Fluid Bed Combustor: Approval was received to proceed with a subcontract with Fluid Bed Combustion Company for the design and cost estimate of the fluid bed combustion system. 


\section{COAL-FUELED MIUS}

A. P. Fraas and W. R. Mixon

This project for analysis, design, and demonstration of a concept utilizing a fluidized-bed coal combustion system as a heat source for a gas turbine generator suitable for applications in Modular Integrated Utility Systems (MIUS) is carried out under the ORNL-HUD-MIUS Frogram within the Energy Division. Work is supported by the U.S. Department of Housing and Urban Development under HUD Interagency Agreement No. 1AA-H-40-72 and by the Energy Research and Development Administration, Office of Fossil Energy (formerly Office of Coal Research, Department of the Interior), under OCR contract No. 14-32-0001-1742. The project consists of four phases: I - Conceptual Preliminary Evaluation; II - Conceptual Design; III - Detailed Design and Construction; and IV - Shakedown, Performance, and Endurance Tests.

\section{$\underline{\text { Summary }}$}

The detailed design effort on Phase III is well under way and procurement negotiations have been started. The request for directive to proceed with procurement and construction has been prepared and is proceeding through channels for approval.

\section{Layout Studies}

The revised furnace design, which reduced the number of flanged joints and requirements for dimensional tolerances, has been firmed up and a full set of layout drawings has been prepared. The revision conforms to the recommendations of the fabricators with whom the furnace construction has been discussed.

A J/12 scale model of the latest layout is being constructed. This will serve to check out the assembly sequence, both initially and for subsequent maintenance operations. In addition it will be helpful in pre-contract negotiations with potential fabricators to clarify the reasons for and the latitude in dimensional requirements.

\section{Turbine-Generator Unit}

Work at AiResearch on their design study contract is continuing. Preliminary results should be available some time in January:

\section{Cold Flow Tests of a Fluidized Bed}

Tests with the $4 \mathrm{ft}$ square cold flow test unit have been resumed. The first of several techniques for investigating the rate at which coal 
particles will be dispersed in the bed has been tried and the preliminary results are being analyzed.

Test of Furnace Gasket Material

A second test employing thicker gasket material has been delayed pending receipt of a test specimen.

\section{Coal Metering and Feed System}

A larger motor has been installed on the Iron Fireman to provide the power required for operation with cold air. Operation of this unit has been satisfactory and tests are proceeding.

The Fire and Safety Departments have raised questions regarding the possibility of coal dust explusions in the bench test laboratory room, and equipment is being grounded. Past experience with coal dust explosions and safety regulations on handling of coal are being reviewed. A report justifying the safety of installed bench test work equipment is being prepared together with estimates of the worst conceivable accidents. This safety evaluation will also be applicable to the full-scale system. 
I. R. G. Affel

2. T. D. Anderson

3. S. I. Auerbach

4. J. K. Baird

5. R. E. Barker

6. H. C. Beeson

7. M. Bender

8. B. G. Blaylock

9. N. E. Bolton

10. R. E. Brooksbank

11. W. A. Bush

12. D. A. Canonico

13. R. S. Carlsmith

14. J. A. Carter

15. H. D. Cochran, Jr.

16. E. Copenhaver

17. L. T. Corbin

18. D. A. Creasia

19. W. K. Crowley

20. 0. L. Culberson

21. F. L. Culler

22. J. E. Cunningham

23. V. A. DeCarlo

24. D. G. Doherty

25. A. S. Dworkin

26. M. S. Edwards

27. F. J. Endelman

28. G. G. Fee

29. D. E. Ferguson

30. I. M. Ferris

31. R. C. Forrester III

32. A. P. Fraas

33. W. Fulkerson

34. W. R. Gambill

35. D. A. Gardiner

36. C. W. Gehrs

37. J. B. Gibson

38. M. R. Guerin

39. C. W. Hancher

4. L. L. A. Harris

41. S. E. Herbes

42. R. M. Hill

43. R. S. Holcomb

44. J. M: Holmes

45. R. B. Honea

46. J. K. Huffstetler

47. C. I. Hunt

48. F. J. Hurst

49. G. R. Jasny, $Y-12$

50. W. F. Johnson
51. L. L. Johnston

52. R. L. Jolley.

53. J. E. Jones.

54. D. S. Joy

55. S. Katz

56. O. I. Keller

57. R. F. Kimball

58. J. J. Kurtz

59. W. R. Laing

60. P. M. Lantz

61. R. S. Livingston

62. A. P. Malinauskas

63. G. B. Marrow, $\mathrm{Y}-\mathrm{I2}$

64. ${ }^{\circ} \mathrm{W}$. R. Martin

65. W. J. McDowell

66: J. R. McWherter

67. C. J. McHargue

68. J. W. Michel

69-71. W. R. Mixon

72. J. E. Mrochek

73. G. E. Moore

74. P. Nettesheim

75-84. J. P. Nichols

85. L. C. Oakes

86. G. R. Peterson

87-88. T. W. Pickel

89. W. W. Pitt

90. H. Postma

91. J. J. Prislinger

92. W. T. Rainey

93. D. E. Reichle

94. C. R. Richmond

95. B. R. Rodgers

96-97. M. W. Rosenthal

98. W. L. Rusocll

99. Royes Salmon

100. R. W. Schede, Y-12

101. C. D. Scott

102. A. J. Shor

103. D. S. Shriner

104. W. D. Shults

105. C. B. Smith

106. G. P. Smith

107. I. Spiewak

108. R. L. Spore

109. E. G. St. Clair

110. J. B. Storer

111. R. A. Strehlow

112. O. K. Tallent

113. E. H. Taylor 
114. A. J. Thompson

115. D. B. Trauger

116. W. C. Ulrich

117. P. R. Vanstrum, Y-12

118. J. S. Watson

119. J. R. Weir

120. P. R. Westmoreland

121. M. E. Whatley

122. J. C. White

123. M. K. Wilkinson
124. I. V. Wilson

125. R. G. Wymer

126. G. L. Yoder

127. C. S. Yust

128. Patent office

129. Lab. Records-RC

130-134. Lab. Records

135-137. Central Research Library

138. Document Reference Sect.

\section{EXTERNAL DISTRIBUTION}

ERDA, Oak Ridge Operations

139. Research and 'I'echnical Support Division

ERDA, Washington

1'io. D. Badlantine

11. J. D. Batchelor, FE (Fossil Energy) 155. W. E. Mott, DBER

142. T. Beresovski, DRRD 156. M. B. Neuworth, FE

143. E. I. Clark, FE

144. N. P. Cochran, FE

145. C. W. Edington, DBER

157. E. S. Pierce, DPR

146. R. Franklin, DBER

158. H. E. Podall, FE

1.47. S. W. Gouse, FE

159. J. L. Powell

148. W. S. Harmon, FE

160. Robert Rabin, DBER

149. G. T. Larson, FE

150. T. K. Lau, FE

151. R. W. A. LeGassie, AA/PA

161. E. Schmetz, FE

162. G. Stapleton, DBER

163. R. E. Vener, FE

164. H. Wasson, DBER

152. J. I. Liverman, AA/ES

165. $\overline{\text { P. }}$. W. White, AA/FE

153. C. Miller, $\mathrm{FE}$

166. R. L. Zahradnik, FE

Department of Housing and Urban Development, 451 th Street, S.W., Washington, D.C. 20410

167. G. S. Leighton

168. J. H. Rothenberg

National Science Foundation, 1800 G Street, N.W., Washington, D. C. 20550

169. R. S. Goor

170. Charles Johnson

Resource Planning Associätes, Inc., 44 Brattle St., Cambridge, Mass. 02138

171. Ruberl Rest

U.S. Environmental Protection Agency, ETRL, 1055 Laidlaw,

Cincinnati, Ohio 45237

172. William E. Pepelko

U.S. Environmental Protection Agency, Research Triangle Park, N.C. 27711

173. Charles B. Sedman 
U.S. Steel Corp. Applied Research. Laboratory, 125 Jamison Lane, Monroeville, Pa. 15146

174. N. S. Boodman, Section Supervisor

University of Kentucky, Institute for Mining and Minerals Research, 213 Bradley Hall, Lexington, Kentucky 40506

175. Theresa Wiley, Institute Librarian

176. 0. J. Haun

177. J. K. Shou

178-189. ERDA Pittsburgh Energy Research Center, U.S. Energy Research and Development Administration, Attention: Director for J. P. Barreca, 4800 Forbes Ave., Pittsburgh, Pa. 15213

190-195. The Director, Morgantown Energy Research Center, P.0. Box 800, Morgantown, West Virginia 26506

196. Tom K. Brotherton, Vice President, Coalcon Company, Union Carbide Corp., P.O. Box 8361, South Charleston, West Virginia 25303

197. D. E. Eissenberg, Union Carbide Corp., 270 Park Ave., New York, N.Y. 10017

198. R. E. Davis, Kerr-McGee Technical Center, P. O. Box 25861, Oklahoma City, Oklahoma 73125

199. H. Beuther, Gulf Research and Development Company, P.O. Drawer 2038, Pittsburgh, Pa. 15230

200. Robert Hangebrauck, National Environmental Research Center, Research Triangle Park, North Carolina 2771l

201. P. H. Given, Pennsylvania State University, College of Earth and Mineral Sciences, University Park, Pa. 16802

202. John W. Larson, Department of Chemistry, University of Tennessee, Knoxville, Tenn. 37916

203. Wendall H. Wiser, University of Utah, Department of Mineral Engineering, Salt Lake City, Utah 84112

204. William A. Peters, Massachusetts Institute of Technology, Department of Chemical Engineering, Cambridge, Mass. 02139

205. Donald Hanson, University of California, Department of Chemical Engineering, Berkeley, California 94720

206. S. G. Wellborn, Manager, Feedstocks Development, E. I. du Pont de Nemours \& Companity, Inc., Wilmington, Delaware 19898

207. Tetra Tech, Inc., 1911 N. Ft. Myer Drive, Suite 601, Arlington, Virginia 22209, Attention: Walter McGough, Jr.

208-209. Jack Gillespie, UCCIN, P. O. Box 1410, Paducah, Ky. 42001 210-236. Technical Information Center, ERDA, ORO 